\title{
Population Dynamics of Fusarium spp. and Microdochium nivale in Crops and Crop Residues of Winter Wheat
}

\author{
J. Köhl, B. H. de Haas, P. Kastelein, S. L. G. E. Burgers, and C. Waalwijk
}

Plant Research International, P.O. Box 16, 6700 AA Wageningen, The Netherlands.

Accepted for publication 20 February 2007.

\begin{abstract}
Köhl, J., de Haas, B. H., Kastelein, K., Burgers, S. L. G. E., and Waalwijk, C. 2007. Population dynamics of Fusarium spp. and Microdochium nivale in crops and crop residues of winter wheat. Phytopathology 97:971-978.

Naturally occurring populations of Fusarium avenaceum, F. culmorum, F. graminearum, F. poae, and Microdochium nivale were studied in two field experiments from anthesis in June 2003 until harvest in crops of winter wheat, and subsequently during 10 months after harvest until June 2004 on their residues exposed on the soil surface under field conditions.

The dynamics of the different pathogens were estimated by quantifying the amount of DNA present in wheat tissues using TaqMan-polymerase chain reaction. While colonization of grain by Fusarium spp. and $M$. nivale was low, high amounts of DNA of $F$. avenaceum, $F$. graminearum, and $F$. culmorum were found in ear residues, internodes, and nodes of the mature crop. Amounts of DNA of pathogens decreased significantly during the following 10 months in residues of internodes and nodes, but not in residues of stem bases. Knowledge on population dynamics of pathogens will help to develop preventive measures aimed at reduction of inoculum sources of head blight pathogens.
\end{abstract}

Head blight of wheat caused by various Fusarium spp. and Microdochium nivale (Fries) Samuels \& I.C. Hallett can result in significant yield losses (19). Furthermore, Fusarium spp. can produce various mycotoxins, e.g., $F$. graminearum Schwabe and F. culmorum (W.G. Sm.) Sacc. produce deoxynivalenol or nivalenol, F. avenaceum (Fr.) Sacc. produces moniliformin, and isolates of $F$. poae (Peck) Wollenweber can produce T2-toxin, HT2-toxin, nivalenol, or fusarenone (5). The presence of mycotoxins results in quality losses of grain for use in food or feed $(5,21)$. Maximum levels for several Fusarium mycotoxins in various commodities have been set by the European Commission (8). F. graminearum, $F$. culmorum, and $M$. nivale were found in the majority of the investigated winter wheat crops in 2000 and 2001 in the Netherlands, but $F$. avenaceum and $F$. poae were also present occasionally (24).

Fusarium spp. and $M$. nivale infect wheat ears primarily during anthesis $(7,19,22)$. Chances for infection depend on many factors, including amount of spores produced in the crop and transported to the ears, weather conditions, and susceptibility of the cultivar. A direct relationship between the amount of inoculum and disease incidence can be expected because head blight epidemics are monocyclic (23). Main sources of inoculum consist of splashdispersed conidia that originate from infected residues of previous crops still present in the field $(6,9,22,23)$. Gibberella zeae (Schwein.) Petch as the sexual stage of $F$. graminearum is able to produce ascospores, which contribute to the local inoculum but also may travel for longer distances so that airborne inoculum produced outside the field may also initiate disease (10). The effect of straw incorporation into soil on the survival of F. culmorum in soil has been studied by Bateman et al. (1), who showed that the presence of straw in the soil generally led to increased pathogen populations in soil samples. Fusarium spp. can also survive in diseased kernels left in the field after harvest as was demonstrated for $F$. graminearum by Inch and Gilbert (12).

Corresponding author: J. Köhl; E-mail address: jurgen.kohl@wur.nl

doi:10.1094/PHYTO-97-8-0971

(c) 2007 The American Phytopathological Society
The objective of our study was to gain insight into the pathogenic colonization of living wheat tissues and the saprophytic colonization of senesced tissues of wheat by different Fusarium spp. and $M$. nivale, and their population dynamics in different types of crop residues under field conditions. TaqMan-polymerase chain reaction (PCR) was used to quantify the amounts of pathogen DNA present in various plant parts at flowering and at harvest as well as in field-exposed crop residues collected at different time points during the 10 months after harvest.

This knowledge on the dynamics of different pathogen populations on crop residues is essential for further optimization of preventive measures such as crop rotation and tillage aiming at reduction of inoculum sources $(6,19)$.

\section{MATERIALS AND METHODS}

Field plots. Crops of soft white winter wheat Triticum aestivum $\mathrm{cv}$. Vivant and residues of these crops were sampled from June 2003 until June 2004 from a clay soil field at Ebelsheerd, northeast Netherlands, and a sandy clay soil field at Lelystad, central Netherlands. The preceding crop was winter wheat on the field at Ebelsheerd and sugar beet on the field at Lelystad. At both locations, plants and plant residues were obtained from each of four replicate plots $(20 \times 3.5 \mathrm{~m})$ not treated with fungicides, which were distributed within experimental fields $(25 \times 60 \mathrm{~m})$ with various treatments arranged in a design with four blocks and complete randomization of treatments within each block. In August 2003, after plots had been harvested with a combine, crop residues were collected between two stubble rows over a distance of 3 to $4 \mathrm{~m}$ separately in each of the four plots. Crop residues in the field at Ebelsheerd consisted of stem fragments and ear residues left over after carting away straw bales. In the field at Lelystad, straw was not carted away and crop residues mainly consisted of complete stems. Thereafter, plant residues were transferred to standardized conditions to reduce the risk of new sources of variation between field plots such as flooding of parts of the field after rainfalls during winter. Sods, approximately $8 \mathrm{~cm}$ in depth, with the standing stubble were cut at five arbitrarily 
chosen parts per replicate plot and placed in five open wooden crates $(60 \mathrm{~cm}$ long, $40 \mathrm{~cm}$ wide, $6.5 \mathrm{~cm}$ high, with $2 \mathrm{~cm}$ interspaces between the slats of the bottom) per replicate plot so that the entire surface was covered by sods. Each crate contained 2 rows of stubble. Distance between rows was $12.5 \mathrm{~cm}$ with approximately 100 stubbles per meter row in Ebelsheerd and 85 stubbles per meter row in Lelystad. The height of stubble was approximately $10 \mathrm{~cm}$. Crop residues from the corresponding plot were placed on the soil between the stubble at a density of $800 \mathrm{~g}$ dry matter per $\mathrm{m}^{2}$ at Ebelsheerd and $600 \mathrm{~g}$ dry matter per $\mathrm{m}^{2}$ at Lelystad. Four sets of five crates, each set representing a replicate plot, were placed on paved surfaces at the margins of the fields. Weather data were collected at the experimental sites with standard meteorological equipment (Fig. 1).

Sampling and sample processing. From each replicate plot, 20 arbitrarily chosen stems were sampled by pulling the stems out of the soil at flowering (16 June 2003) and at harvest (30 July 2003) and kept at $5^{\circ} \mathrm{C}$ after sampling. Stems were dissected to separate ears, completely senesced leaves, green or partly necrotic leaves, nodes, internodes, and stem bases within $24 \mathrm{~h}$. Stem bases, defined as the stem part between the crown roots and the first node, were rinsed with tap water to remove adhering soil. Grain was separated from ripe ears by a laboratory thresher (Pelz, Bonn, Germany) and cleaned with a South Dakota seed blower (Seedburo Equipment Company, Chicago) to obtain separate samples of grain and ear residues. Plant parts from 10 stems per replicate plot were put into plastic vials immediately after cutting and stored at $-18^{\circ} \mathrm{C}$. After storage, samples were freeze-dried and subsequently pulverized in a laboratory mill with a $1-\mathrm{mm}$ mesh sieve. The mill was cleaned with pressurized air and rinsed with ethanol $(70 \%)$ after sample processing. Powdered samples were stored at $-18^{\circ} \mathrm{C}$ for DNA extraction. Plant parts of the remaining 10 stems were dried at $105^{\circ} \mathrm{C}$, and the dry matter contents were weighed.

Twenty stubble pieces, 20 straw pieces, and 3 to $6 \mathrm{~g}$ of ear residues, consisting of rachis and glumes, per replicate were collected arbitrarily from each set of five crates on 3 September, 6 October, and 2 December 2003 and 4 February, 6 April, and 17 June 2004. Residues of stubble and straw collected after harvest were separated into nodes, internodes, and stem bases. Long parts of internodes were cut into 1- to 2-cm pieces, and subsamples of approximately 5 to $10 \mathrm{~g}$ were obtained. Nodes from stubble and straw were pooled. The same was done with internodes from above the first node of stubble and straw. All samples of plant parts were freeze-dried and subsequently pulverized in a laboratory mill with a $1-\mathrm{mm}$ mesh sieve. Sample powders were stored at $-18^{\circ} \mathrm{C}$. At Lelystad, straw residues from an additional 10 stems per replicate were sampled at all sampling dates and were separated into the various plant parts and dried at $105^{\circ} \mathrm{C}$, and the dry matter contents were weighed.

DNA extraction. DNA was extracted from 10- to $15-\mathrm{mg}$ subsamples of plant tissues that had been freeze-dried and milled. DNA extraction was performed with the DNeasy plant mini kit (Qiagen, Westburg, Germany) according to the protocol supplied by the manufacturer. The DNA was eluted in two steps, each with $50 \mu \mathrm{l}$ of elution buffer supplied with the extraction kit, and both elutions were combined.

Primers and probes including the internal control. The primers and probes for $F$. avenaceum, $F$. culmorum, $F$. graminearum, F. poae, and M. nivale as well as the internal control, Potato leaf roll virus, as developed by Waalwijk et al. (25) were used. The internal control was slightly changed as the original reporter and quencher molecules were replaced by Yakima Yellow at the 5' end and Eclips Dark Quencher (Eurogentec) at the 3' end.

Real-time PCR. Separate TaqMan reactions were carried out to quantify $F$. avenaceum, $F$. culmorum, $F$. graminearum, $F$. poae, and $M$. nivale with each reaction containing the internal control. TaqMan reactions were performed in a 96-well format in an ABI Prism 7700 apparatus according to the protocol of Waalwijk et al. (25). For each 96-well plate used, a 10-fold serial dilution ranging from $9,000 \mathrm{pg}$ down to $0.9 \mathrm{pg}$ of the corresponding pathogen DNA (obtained from pure culture) was run in parallel for cali-
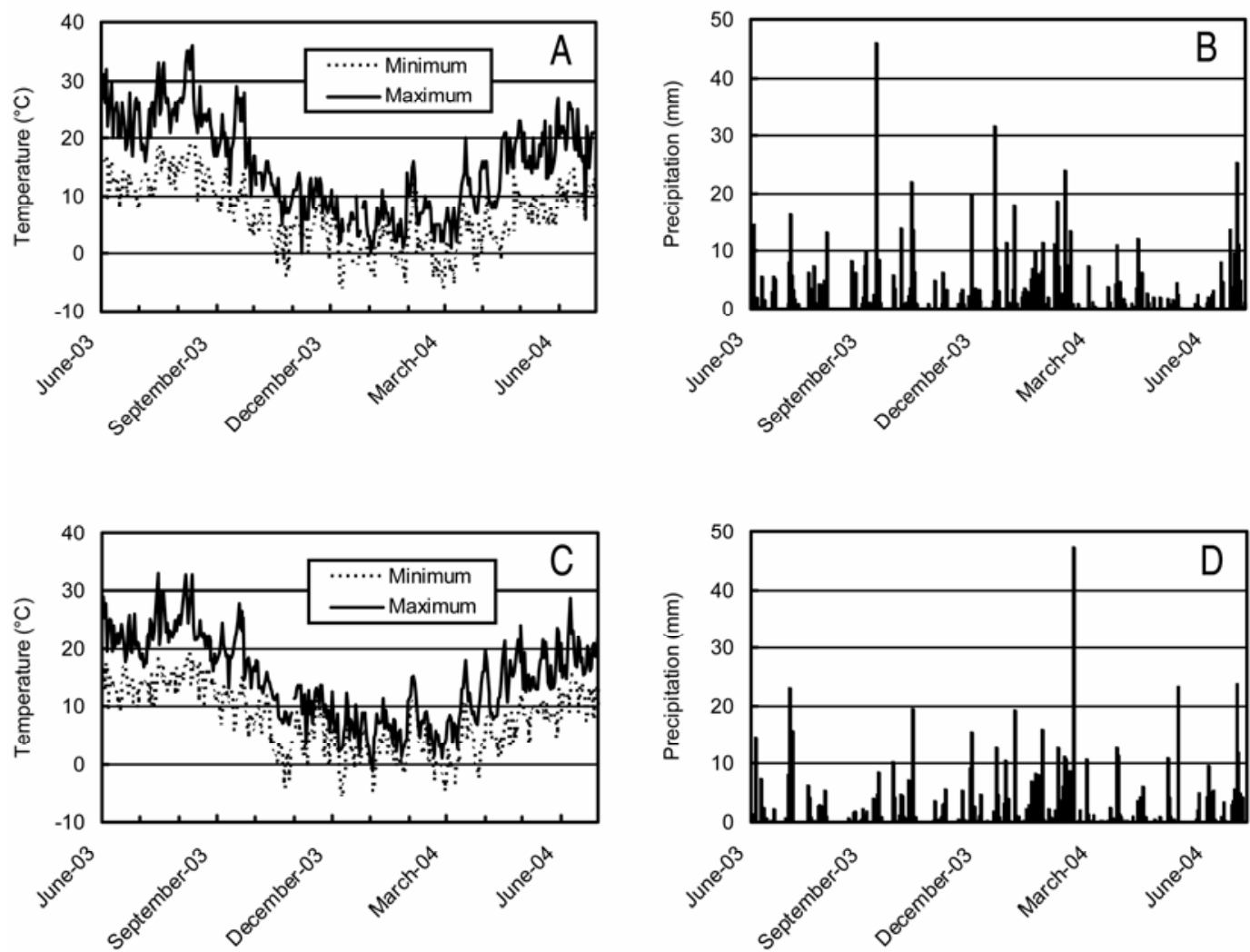

Fig. 1. A and C, Daily maximum and minimum temperature and $\mathbf{B}$ and $\mathbf{D}$, daily precipitation at Ebelsheerd (A and $\mathbf{B})$ and Lelystad $(\mathbf{C}$ and $\mathbf{D})$. 
bration. Measurements obtained for samples that showed suppression of the internal control amplification were not included in data analysis, but the TaqMan reactions were repeated after 10fold dilution.

Statistics. TaqMan measurements were repeated for several samples for the various pathogens and plant parts to estimate the accuracy of pathogen quantification and the contribution of several steps of the quantification procedure such as DNA extraction, dilution of DNA extracts, and TaqMan-PCR to the possible variance between measurements. These repeated measurements were done in separate TaqMan-PCR runs (at different dates). From 51 samples, the same DNA extracts at the same dilution factors were analyzed twice. From 55 samples, DNA extracts were analyzed with and without a 10-fold dilution step. From another 51 samples, DNA was extracted from different subsamples and analyzed. Variances were estimated separately for the natural-log-transformed data $\left(x^{\prime}=\operatorname{Ln}(x+1)\right.$, where $x$ is $\mathrm{pg}$ of DNA) for these three groups of paired measurements. This resulted in a coefficient of variation (in percentage) on the original scale.

The experimental design consisted of four plots at two locations that were sampled at eight different sampling dates. At each time, new randomly chosen plant material was taken since the assessments were destructive. In this experiment, time itself is a treatment of interest. Instead of using different experimental plots for each time-location combination, more substantial plots were used and subsampled at various times. It was tested in an analysis of variance (ANOVA) for repeated measurements (procedure AREPMEASURES in Genstat) whether or not the variancecovariance structure showed compound symmetry (i.e., a uniform covariance structure). If this was not the case, GreenhouseGeisser epsilon was used as correction factor for the degrees of freedom in the subsequent analysis of variance and least significant difference (LSD) tests to correct for temporal autocorrelation (11). ANOVA was performed taking into account the two levels of variation, i.e., location was tested against variation between plots and the treatment time and the interaction between location and time was tested against the residual (plot-time variation). For each pathogen, a separate ANOVA was done per plant tissue after natural-log-transformation (Ln) of data $\left(x^{\prime}=\operatorname{Ln}(x+1)\right.$, where $x$ is pg of DNA). Fisher's protected LSD was used for mean comparisons (18).

Data analysis was performed with GENSTAT 7 (Genstat Committee, Algorithm Group Inc.).

\section{RESULTS}

Variation between repeated measurements. Measurements by TaqMan-PCR were repeated on different 96-well plates for various combinations of pathogens and plant tissues using the same DNA extracts at the same dilution, same extracts at different dilutions, or independent DNA extractions from different subsamples. The overall coefficient of variation $(\mathrm{CV})$ was $84 \%(n=$ 51) at the original scale ( $\mathrm{pg}$ of DNA $\mathrm{mg}^{-1}$ ) for repeated independent measurements of the same DNA extracts at the same dilution (Table 1). Variation was lower for samples with higher DNA concentrations, e.g., the variation coefficient was $\mathrm{CV}=38 \%$ $(n=35)$ for samples with values above $20 \mathrm{pg}$ of DNA mg ${ }^{-1}$ but much higher for samples with low DNA concentrations (e.g., for the four sample pairs with values below $20 \mathrm{pg}$ of DNA mg${ }^{-1}$, the variation coefficient was $\mathrm{CV}=111 \%[n=4]$ ). Variation was not higher for repeated measurements of samples at different dilutions or for samples obtained from different subsamples from the same samples of milled plant tissues. The ANOVA components indicated that the main source for variation between repeated measurements is the TaqMan-PCR procedure itself, especially for low values derived from high cycle threshold $\left(C_{t}\right)$ values, but not subsampling, DNA extraction, or dilution of DNA extracts before DNA quantification. Analysis of the same data set separately for the different fungal species or types of plant tissues gave no further insight in sources of variation since no species or tissue could be identified giving systematically higher or lower variation between repeated measurements. Given the level of DNA concentrations in the truly replicated field samples and their substantial changes in time, it was concluded that repeated measurements of samples as pseudoreplicates were not necessary to obtain conclusive results on biologically significant chances of population sizes in time.

Colonization of leaves. $M$. nivale was found on both senesced leaves and (partly) green leaves at flowering as well as at harvest

TABLE 1. Coefficients of variation for repeated measurements of DNA contents of Fusarium spp. or Microdochium nivale in winter wheat tissue samples by TaqMan-polymerase chain reaction

\begin{tabular}{|c|c|c|c|c|}
\hline \multirow[b]{2}{*}{ DNA extraction } & \multirow[b]{2}{*}{$\begin{array}{l}\text { Dilutions of target } \\
\text { DNA solution }\end{array}$} & \multicolumn{3}{|c|}{ Coefficient of variation (number of repeated measurements) ${ }^{y}$} \\
\hline & & For all values & $\begin{array}{c}\text { For values }<20 \mathrm{pg} \text { of DNA } \\
\mathrm{mg}^{-1} \text { of wheat tissue }\end{array}$ & $\begin{array}{c}\text { For values }>20 \text { pg of DNA } \\
m^{-1} \text { of wheat tissue }\end{array}$ \\
\hline Same extraction & $2.5 \mu \mathrm{l}$ per $30 \mu \mathrm{l}$ & $84 \%(51)$ & $111 \%(4)$ & $38 \%(35)$ \\
\hline $\begin{array}{l}\text { Separate extractions from } \\
\text { different subsamples }\end{array}$ & $2.5 \mu \mathrm{l}$ per $30 \mu \mathrm{l}$ & $65 \%(55)$ & $88 \%(13)$ & $35 \%$ (39) \\
\hline
\end{tabular}

${ }^{\mathrm{y}}$ For data pairs with values $>0 \mathrm{pg} \mathrm{mg}^{-1}$.

${ }^{\mathrm{z}}$ For data pairs with both values fulfilling the criterion.

TABLE 2. Colonization of leaves of winter wheat cv. Vivant by Fusarium spp. and Microdochium nivale at flowering and harvest

\begin{tabular}{|c|c|c|c|c|c|c|}
\hline \multirow[b]{2}{*}{ Leaf tissue } & \multirow[b]{2}{*}{ Sampling time } & \multicolumn{5}{|c|}{ Concentration of fungal DNA [ $\mathrm{Ln}\left(\mathrm{pg}\right.$ of DNA mg ${ }^{-1}$ of leaf tissue +1$\left.)\right]^{\mathrm{z}}$} \\
\hline & & F. avenaceum & F. culmorum & F. graminearum & F. poae & M. nivale \\
\hline \multicolumn{7}{|l|}{ Ebelsheerd } \\
\hline Green & Flowering & $1.02 \pm 2.03(2)$ & $0.00 \pm 0.00(0)$ & $0.00 \pm 0.00(0)$ & $0.79 \pm 0.93(1)$ & $3.64 \pm 0.56(37)$ \\
\hline Necrotic & Harvest & $6.33 \pm 0.20(560)$ & $1.42 \pm 1.27$ & $4.58 \pm 0.60(97)$ & $0.73 \pm 0.87(1)$ & $5.63 \pm 0.22(278)$ \\
\hline \multicolumn{7}{|l|}{ Lelystad } \\
\hline Green & Flowering & $0.00 \pm 0.00(0)$ & $1.05 \pm 2.11(2)$ & $0.00 \pm 0.00(0)$ & $0.32 \pm 0.64(0)$ & $4.54 \pm 0.34$ \\
\hline
\end{tabular}

${ }^{\mathrm{z}}$ Mean \pm standard deviation of four replicates; backtransformed values of the means in brackets. 
(Table 2). Only traces of Fusarium spp. were found on green leaves at flowering, but senesced leaves contained substantial amounts of $F$. avenaceum with 560 and $153 \mathrm{pg}$ of DNA mg (backtransformed values) at Ebelsheerd and Lelystad at harvest, respectively. $F$. culmorum and $F$. graminearum were also present on senesced leaves at harvest, but at lower densities.

Colonization of ears. No symptoms of Fusarium-incited diseases were observed on stem bases, leaves, or ears on the stems sampled at flowering at either location. All spikelets of ears sampled at harvest without or with symptoms of Fusarium head blight (coloration caused by the presence of sporodochia) were counted. Only $0.3 \%$ of the spikelets at Ebelsheerd showed symptoms. Spikelets at Lelystad showed no symptoms. No Fusarium spp. were detected by TaqMan-PCR on ears sampled at flowering in June 2003. M. nivale was present on ears at flowering in Ebelsheerd in low amounts, $7 \mathrm{pg}$ of DNA mg-1 At harvest, the four Fusarium spp. and $M$. nivale were found in grains as well as ear residues, consisting of rachis and glumes, at both locations (Table 3). In grain, $F$. avenaceum was the dominating species in Ebelsheerd, whereas $F$. culmorum was dominating in Lelystad. Interestingly, colonization of ear residues by Fusarium spp. or $M$. nivale always was higher than that of grain, e.g., 1,771 pg of DNA mg ${ }^{-1}$ of $F$. avenaceum was found in ear residues compared with 203 pg of DNA mg-1 in grain in Ebelsheerd and $601 \mathrm{pg}$ of DNA mg ${ }^{-1}$ of F. culmorum was found in ear residues compared with $91 \mathrm{pg}$ of DNA $\mathrm{mg}^{-1}$ in grain in Lelystad.

Colonization of stem tissues. All four Fusarium spp. and $M$. nivale could be detected in nodes, internodes, and stem bases at both locations. Colonization of these plant parts by F. culmorum was significantly higher for most sampling dates in Lelystad than in Ebelsheerd, and colonization by $F$. avenaceum was significantly lower (Fig. 2; Table 4). In Ebelsheerd, colonization of internodes by $F$. graminearum and of nodes and internodes by $F$. poae was also significantly higher than in Lelystad. The colonization of the nodes and internodes by Fusarium spp. and $M$. nivale was not detectable at flowering and peaked at harvest after which populations began to decline from autumn through early summer. In June 2004, 10 months after harvest, F. avenaceum and $F$. graminearum could only be detected in nodes and internodes sampled in Lelystad with 218 and 23 pg of DNA mg ${ }^{-1}$ in nodes and 92 and $46 \mathrm{pg}$ of DNA mg-1 in internodes, respectively. In all other cases, populations of Fusarium spp. decreased to levels not statistically different from zero or were not found in the samples. In contrast to the four Fusarium spp., $M$. nivale was already present in nodes and internodes at flowering in June 2003. Like the populations of Fusarium spp., the populations of $M$. nivale increased during maturation, peaked at harvest, and consistently decreased after harvest. In June 2004, population levels were close to zero.

In stem bases, a different pattern was found for population dynamics for $F$. avenaceum, $F$. culmorum, $F$. graminearum, and $M$. nivale. Considerable amounts of $M$. nivale at both locations and of $F$. avenaceum at Ebelsheerd were already established in the stem base at flowering in June 2003. F. avenaceum, F. culmorum, and $F$. graminearum did not decrease significantly in the stem bases after harvest, as these species did in nodes and internodes. In contrast, colonization of stem bases by $M$. nivale peaked after harvest in September 2003 and subsequently decreased significantly during winter and spring. Colonization by $F$. poae was low at both locations.

In the experiment at Lelystad, the quantity of node tissue, internode tissue, and stem base tissue produced per stem was determined and further monitored during the course of the experiment until June 2004 so that the rate of decomposition could be estimated per tissue type. Dry weights of internode tissue per stem decreased remarkably over time, whereas weights of node and stem base tissue remained almost constant (Fig. 3). For this experiment, the amounts of Fusarium spp. and M. nivale present in the different tissues during time were calculated (Table 5). At harvest, most DNA of Fusarium spp. and M. nivale was present in nodes and internodes, but after exposure of crop residues to field conditions for 10 months, the main parts of the fungal populations were present in the remains of stem bases (Table 5). From the total amounts of DNA of Fusarium spp. and M. nivale present in the different substrates, it can be estimated that at harvest, stem bases contributed $14 \%$ to the total amount of DNA of $F$. avenaceum present per stem (without the ear and leaves). For $F$. culmorum, F. graminearum, F. poae, and M. nivale, these contributions were $2,<1,6$, and $2 \%$, respectively. The majority of F. avenaceum DNA was present in the nodes, and for the other pathogens, this occurred in internodes. In June 2004, DNA amounts in residues of nodes and internodes were less than $0.1 \%$ of values found at harvest. Such huge reductions of populations (as estimated by DNA quantification) were not found in residues of stem base tissue. Indeed, the amount of $F$. graminearum DNA present in stem base tissue even increased ninefold. As a consequence, most of the DNA of the different fungi was present in stem base tissue in June 2004, contributing 87, >99, >99, 33 , and $85 \%$ to the total amount found on stem residues (except those of ears or leaves) for $F$. avenaceum, $F$. culmorum, $F$. graminearum, $F$. poae, and $M$. nivale, respectively.

\section{DISCUSSION}

Quantification of DNA by TaqMan-PCR depends on standardized extraction of the fungal DNA from the substrate. Thus, differences in matrix structure of different tissues may affect extraction efficiency and consequently interfere with DNA quantification. Moreover, due to decomposition, matrix characteristics may change over time. The applied DNA extraction protocol was developed for wheat tissues in an earlier study (25) considering quantity and integrity of extracted fungal and plant DNA to minimize such risks. An internal control was always used to detect possible interference of extracts from different substrates with DNA amplification. The $\mathrm{C}_{\mathrm{t}}$ values of TaqMan reactions for internal controls were similar for most samples. A systematic effect of matrix characteristics on DNA extraction and amplification is, thus, not very likely. In the few cases where the quantification of the internal control was underestimated, measurements were repeated with diluted DNA solutions. No suppression of internal controls was observed in these cases. Analysis of the observed

TABLE 3. Colonization of grains and ear residues of winter wheat cv. Vivant by Fusarium spp. and Microdochium nivale at harvest

\begin{tabular}{|c|c|c|c|c|c|}
\hline \multirow[b]{2}{*}{ Ear tissue } & \multicolumn{5}{|c|}{ Concentration of fungal DNA [ $\mathrm{Ln}\left(\mathrm{pg}\right.$ of DNA mg ${ }^{-1}$ of ear tissue +1$\left.)\right]^{\mathrm{z}}$} \\
\hline & F. avenaceum & F. culmorum & F. graminearum & F. poae & M. nivale \\
\hline \multicolumn{6}{|l|}{ Ebelsheerd } \\
\hline Grain & $5.32 \pm 0.28(203)$ & $0.76 \pm 1.51$ & $2.08 \pm 2.92(7)$ & $2.77 \pm 1.30(15)$ & $2.62 \pm 0.52(13)$ \\
\hline Residues & $7.48 \pm 0.26(1,771)$ & $2.25 \pm 2.49$ & $5.79 \pm 0.98(326)$ & $4.63 \pm 0.74(102)$ & $4.20 \pm 0.80(66)$ \\
\hline \multicolumn{6}{|l|}{ Lelystad } \\
\hline Grain & $1.06 \pm 2.11(2)$ & $4.52 \pm 1.08(91)$ & $1.67 \pm 3.33(4)$ & $1.65 \pm 0.37(4)$ & $2.03 \pm 1.37(7)$ \\
\hline Residues & $4.96 \pm 0.53(142)$ & $6.40 \pm 0.45(601)$ & $4.70 \pm 3.28(109)$ & $2.83 \pm 1.14(16)$ & $4.94 \pm 0.35(139)$ \\
\hline
\end{tabular}

${ }^{\mathrm{z}}$ Mean \pm standard deviation of four replicates; backtransformed values of the means in brackets. 

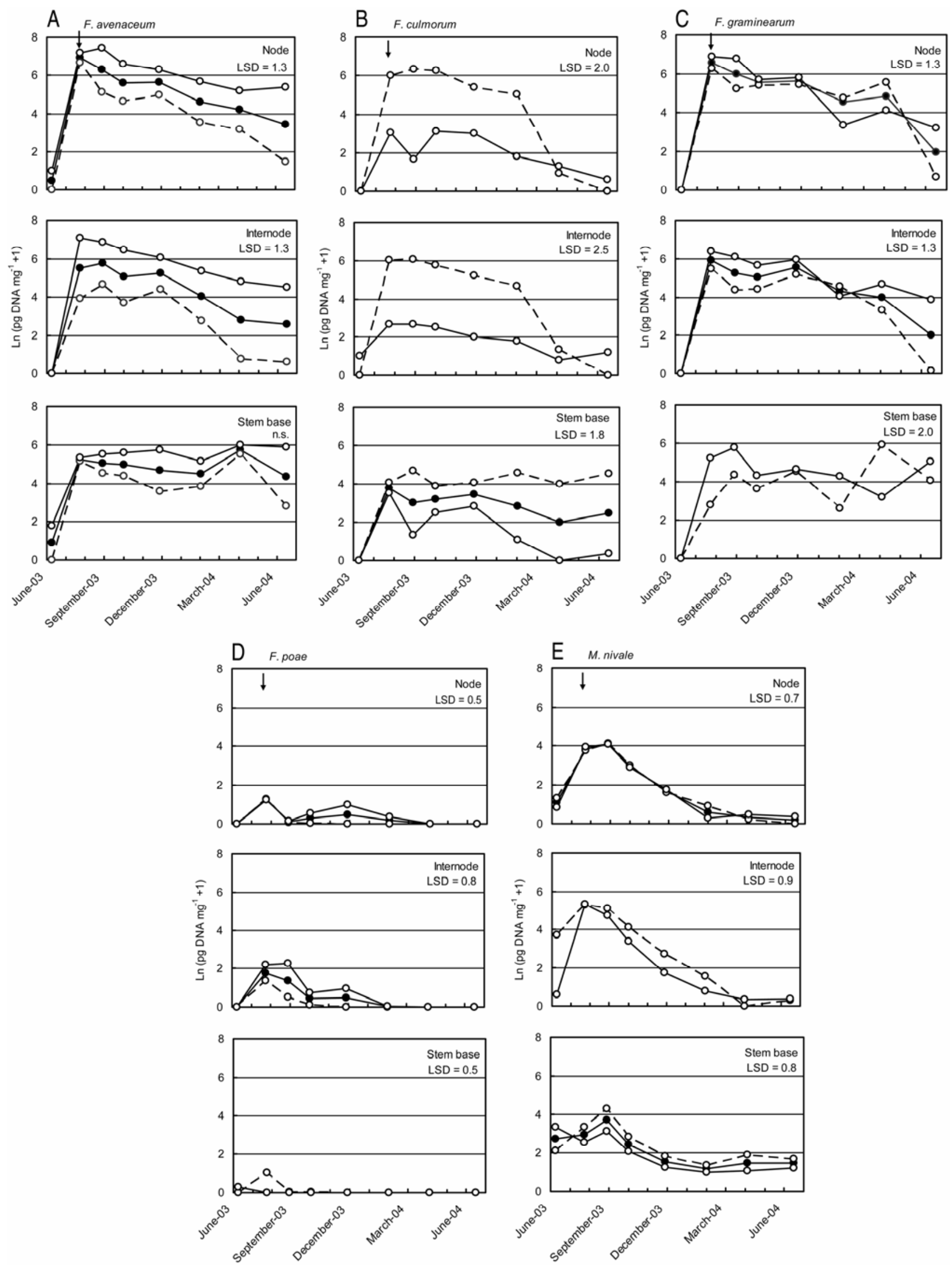

Fig. 2. Population dynamics of Fusarium spp. and Microdochium nivale in stem tissues of crops of winter wheat cv. Vivant and their residues sampled in the field experiments at Ebelsheerd (- $\left.-{ }_{-}-\right)$and Lelystad (-----o-----). Means of both locations and corresponding LSD values $(\alpha=0.05)$ are presented if no timelocation interaction was observed (---------). In case of time-location interaction, LSD values $(\alpha=0.05)$ indicate statistically significant differences between data points per location. n.s. indicates no significant differences. Arrow indicates harvest date. A, F. avenaceum; B, F. culmorum; C, F. graminearum; D, F. poae; and $\mathbf{E}, M$. nivale. 
TABLE 4. Population dynamics of Fusarium spp. and Microdochium nivale in stem tissues of crops of winter wheat cv. Vivant and their residues sampled in the field experiments at Ebelsheerd and Lelystad

\begin{tabular}{|c|c|c|c|}
\hline \multirow[b]{2}{*}{$\begin{array}{l}\text { Pathogen } \\
\text { Plant tissue }\end{array}$} & \multicolumn{3}{|c|}{$F$ probability $^{\mathrm{z}}$} \\
\hline & Location & $\begin{array}{l}\text { Sampling } \\
\text { time }\end{array}$ & $\begin{array}{c}\text { Location } \times \\
\text { sampling time }\end{array}$ \\
\hline \multicolumn{4}{|l|}{ F. avenaceum } \\
\hline Node & 0.001 & 0.002 & 0.149 \\
\hline Internodium & $<0.001$ & $<0.001$ & 0.077 \\
\hline Stem base & 0.013 & 0.438 & 0.277 \\
\hline \multicolumn{4}{|l|}{ F. culmorum } \\
\hline Node & 0.002 & $<0.001$ & 0.002 \\
\hline Internodium & 0.040 & $<0.001$ & 0.012 \\
\hline Stem base & 0.011 & 0.004 & 0.118 \\
\hline \multicolumn{4}{|c|}{ F. graminearum } \\
\hline Node & 0.149 & $<0.001$ & 0.135 \\
\hline Internodium & 0.020 & $<0.001$ & 0.108 \\
\hline Stem base & 0.036 & $<0.001$ & 0.045 \\
\hline \multicolumn{4}{|l|}{ F. poae } \\
\hline Node & 0.032 & $<0.001$ & 0.527 \\
\hline Internodium & 0.020 & $<0.001$ & 0.244 \\
\hline Stem base & 0.266 & 0.034 & 0.016 \\
\hline \multicolumn{4}{|l|}{ M. nivale } \\
\hline Node & 0.692 & $<0.001$ & 0.864 \\
\hline Internodium & $<0.001$ & $<0.001$ & $<0.001$ \\
\hline Stem base & 0.298 & $<0.001$ & 0.167 \\
\hline
\end{tabular}

${ }^{\mathrm{z}}$ Results of analysis of variance for each combination of pathogen and plant tissue tested separately. Location was tested against variation between plots and sampling time was tested against within-plot variation.

variation between measurements of the same samples indicated considerable variation between individual TaqMan reactions, but variation did not increase when DNA extracted from different subsamples or at different dilution steps was compared. The accuracy of quantification of the fungal populations can, thus, further be improved by repeated measurements of the same DNA solutions without the need of labor-intensive prior subsampling combined with separate DNA extractions.

Similar patterns of population dynamics were found in stem tissues of winter wheat at both locations although population levels of individual Fusarium spp. differed among species and locations. Observations were made only during one season with a mild winter with temperatures below $0^{\circ} \mathrm{C}$ only for a few days (Fig. 1). Furthermore, crop residues were exposed to standardized conditions on soil in open crates that were placed on paved ground to allow drainage of water. Thus, microclimatic conditions differed from true field conditions. Further field experiments are needed to show whether the observed patterns of population dynamics in Fusarium spp. are typical for the particular season with a low disease incidence or occur more, in general, under field conditions.

Fusarium spp. were almost absent at flowering, but colonization increased sharply at maturation. It can be assumed that conidia of Fusarium spp. and M. nivale as well as ascospores of $F$. graminearum are produced on crop residues under favorable environmental conditions during the entire cropping period (9). Furthermore, conidia of Fusarium spp. may be produced on infected ears. After spreading, mainly by splash dispersal, this inoculum may be present on surfaces of wheat tissues. Resistance of wheat tissues against infection by the Fusarium spp. and $M$. nivale may decrease during maturation so that the pathogens are able to invade the different tissues. Their potential to infect in this situation as weak pathogens may allow rapid colonization of the tissue before other nonpathogenic fungi present on the tissues surfaces, e.g., Cladosporium spp., are able to colonize the tissues saprophytically. A higher incidence of $F$. graminearum at harvest in nodes than in kernels or floral bracts was also observed by Pereyra and Dill-Macky (20) after artificial inoculation of a wheat crop.

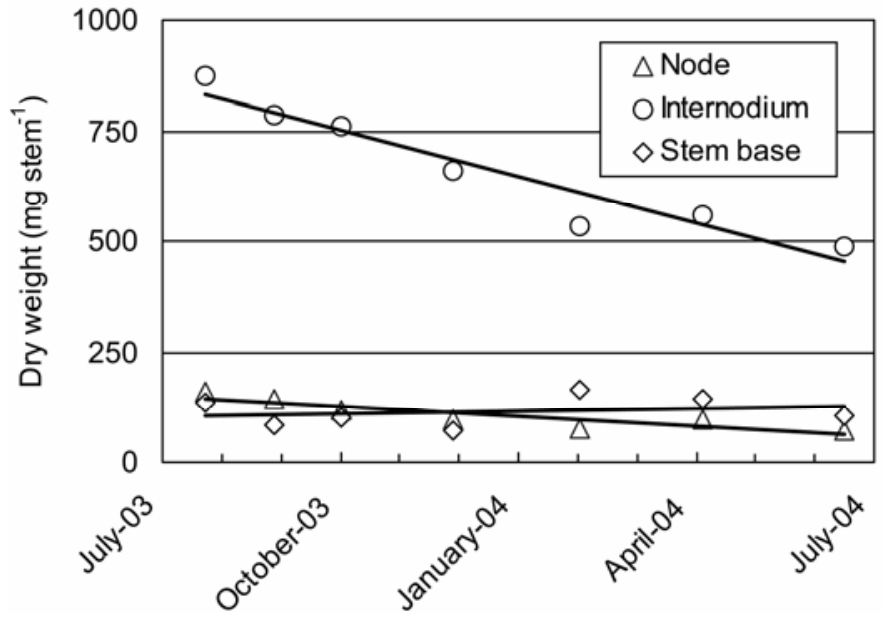

Fig. 3. Temporal changes in the dry weight of node, internode and stem base tissues present on field soil at Lelystad (mg dry weight per stem). Means of four replicates. Regression lines (with $x=0$ for harvest date at 30 July 2003) were: $y=-0.25 x+144.01 ; R^{2}=0.77 ; F$ probability $=0.009$ for nodes; $y=$ $-1.18 x+833.06 ; R^{2}=0.92 ; F$ probability $<0.001$ for internodes; and $y=$ $0.06 x+105.12 ; R^{2}=0.05 ; F$ probability $=0.628$ for stem bases

After harvest, the amount of Fusarium spp. or M. nivale in nodes and internodes decreased during autumn and winter with a further sharp decrease in spring of the following year. A similar decrease was found by Khonga and Sutton (15) for stems and kernels of both wheat and maize that had been autoclaved, artificially inoculated with $G$. zeae ( $F$. graminearum), and incubated for 4 weeks before being placed in the field.

Surprisingly, a different pattern was found for population dynamics in stem bases, where the pathogens showed fluctuations over time without any tendency to decrease. The observed decrease of pathogen DNA in internodes and nodes after harvest could be explained in part by transformation of mycelial biomass into survival structures such as chlamydospores as a consequence of nutrient depletion or other forms of environmental stress. Moreover, the population decrease of Fusarium spp. and M. nivale may result from competitive colonization of substrates by other microorganisms (3). Crop residues precolonized by Fusarium spp. before being exposed to soil may be colonized by a succession of various soil inhabiting microorganisms. Bowen (3) studied colonization and decomposition of straw by mixed fungal species, including $F$. culmorum and several lignin decomposing basidiomycetes. In most cases, mixed inoculation led to increased decomposition. Bowen (3) stated that the initial straw colonizing species may not necessarily continue to occupy these niches but can be replaced by more efficient decomposers such as Chaetomium globosum Kunze ex Fries. Fusarium spp. may colonize wheat stem tissues during maturation of the crop as weak pathogens, but may be out-competed by more aggressive saprophytic fungi entering the senesced tissues since the carrying capacity of necrotic plant tissues for fungal populations is limited. Such competitive substrate colonization by pathogens and saprophytes is a powerful mechanism in biological control of plant diseases (14). A thorough analysis of microbial successions in residues of wheat crops precolonized by different Fusarium spp. may explain the unexpected decrease of Fusarium spp. in nodes and internodes.

The observed different population dynamics in stem bases may be due to different substrate composition, late colonization of stem bases by Fusarium spp. via infected roots as supposed for maize stalks (23), or a slightly different microclimate resulting from the different positions of the substrate types on the soil surface. Stem bases remained attached to root residues and were positioned primarily upright during the experiments, whereas the other stem tissues were detached and laid horizontally on the soil 


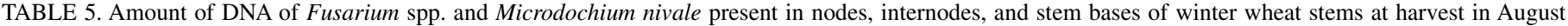
2003 and after exposure to field conditions in June 2004 (field experiment at Lelystad)

\begin{tabular}{|c|c|c|c|c|c|}
\hline \multirow[b]{2}{*}{ Sampling date } & \multicolumn{5}{|c|}{ Amount of DNA present in wheat tissue $\left[\operatorname{Ln}\left(\mathrm{pg} \text { of DNA stem }{ }^{-1}+1\right)\right]^{\mathrm{y}}$} \\
\hline & F. avenaceum & F. culmorum & F. graminearum & F. poae & M. nivale \\
\hline \multicolumn{6}{|l|}{ Node } \\
\hline August 2003 & $11.74 b^{\mathrm{z}}(125,491)$ & $11.07 \mathrm{~b}(64,215)$ & 11.32 b $(82,453)$ & $5.49 \mathrm{~b}(241)$ & $8.78 \mathrm{~b}(6,502)$ \\
\hline June 2004 & 2.59 a (12) & $0.00 \mathrm{a}(0)$ & 1.77 a (5) & $0.00 \mathrm{a}(0)$ & 0.00 a $(0)$ \\
\hline \multicolumn{6}{|l|}{ Internodium } \\
\hline August 2003 & $9.01 \mathrm{~b}(8,184)$ & $12.79 \mathrm{~b}(358,612)$ & $12.24 \mathrm{~b}(206,901)$ & $6.25 \mathrm{~b}(517)$ & $12.06 \mathrm{~b}(172,818)$ \\
\hline June 2004 & $2.15 \mathrm{a}(8)$ & $0.00 \mathrm{a}(0)$ & $1.50 \mathrm{a}(3)$ & $0.00 \mathrm{a}(0)$ & 2.91 a (17) \\
\hline \multicolumn{6}{|l|}{ Stem base } \\
\hline August 2003 & $10.00 \mathrm{~b}(22,025)$ & 8.91 a $(7,405)$ & 6.39 a (595) & $3.84 \mathrm{~b}(46)$ & 8.19 a $(3,604)$ \\
\hline June 2004 & 5.03 a (152) & 8.05 a $(3,133)$ & 8.59 a $(5,377)$ & $0.00 \mathrm{a}(0)$ & $4.80 \mathrm{a}(121)$ \\
\hline
\end{tabular}

y Backtransformed values in brackets.

${ }^{\mathrm{z}}$ Values per fungal species and tissue type with a common letter are not statistically different (LSD; $\left.P=0.05\right)$.

surface. This set-up was chosen to mimic the situation of direct drilling.

Observations were made at two different locations, but only during a season with low head blight incidence, in one cultivar, and a tillage system mimicking direct drilling. Further assessments are needed on population dynamics of Fusarium spp. and $M$. nivale in different seasons, different tillage systems, and various crop rotations. Knowledge of the reasons for the striking differences in population dynamics in stem bases versus nodes and internodes may help to develop improved preventive measures, e.g., optimizing the microclimate for enhanced colonization by microbial competitors and decomposers. The putative importance of stem bases in contrast to internodes or nodes as a niche for long-term survival of inoculum of Fusarium spp. and $M$. nivale may also imply special attention, e.g., during tillage to specifically target stubble. Moreover, control measures such as biological control aimed at reduction of inoculum $(4,16)$ should also be targeted primarily at stem bases, and treatment of straw might be of lesser importance.

Compared with the amounts of pathogen DNA found in grain at harvest, consistently more DNA of Fusarium spp. and M. nivale were found in ear residues and stem parts. It is therefore possible that higher mycotoxin contents were present in straw than in grain. Higher DON concentrations in nodes and internodes of winter wheat than in grain were determined in field samples obtained in 2005 (J. Köhl, B. H. de Haas, and P. Kastelein, unpublished data). Also, this aspect needs attention in further research on Fusarium diseases of wheat since most straw is harvested in the Netherlands for use in animal production or crop production, e.g., production of flower bulbs, strawberries, and mushrooms may be exposed to dust originating from straw.

Several TaqMan-PCR systems for quantification of Fusarium spp. have been developed recently $(2,25,27)$ and these are mainly used for detection in grain. Our study demonstrated the use of such techniques in epidemiological studies. Compared with traditional plating techniques or histological methods (13), real-time PCR allows the processing of large numbers of samples because it is much less laborious. Furthermore, the quantification of DNA using species-specific primers and probes in plant tissues avoids several typical problems of species-specific quantification of mycelial fungi by plating techniques: (i) production of standardized mycelial fragments by homogenization depends on the texture of the plant tissue which changes with decomposition. The size of mycelial fragments decreases with the degree of homogenization but the percentage of disrupted cells in fragments also increases; (ii) formation of colonies on agar depends on the medium used; (iii) presence of other microorganisms on the agar plates results in competition and possibly antibiosis so that the target colony forming units may be underestimated especially if present in low quantities; and (iv) determination of fungi to species level is not possible in all cases on dilution plates and may require subcul- turing under specific conditions and expertise. Alternatively, fragments of infested plant tissues can be plated without homogenization to assess the incidence of a fungal species on the plant tissue fragments $(15,17,20,23,26)$. In this case, incidence depends on fragment size and a differentiation in colonization intensities is impossible if incidences are high. However, to our knowledge, no detailed studies have been published comparing plating techniques for species-specific quantification of mycelial fungi with TaqMan-PCR. The TaqMan-PCR data obtained in our study showed considerable variability especially for low concentrations of Fusarium spp. which can be explained by the higher $\mathrm{C}_{\mathrm{t}}$ values of the TaqMan-PCR needed for detection. Variability caused by possible slight amplification inefficiencies of the PCR increases with the number of cycles needed for detection. If a higher precision is required, variation can be lowered by repeating measurements of DNA extracts.

The novel possibilities of monitoring Fusarium spp. and $M$. nivale populations in different wheat production practices will allow better insights in inoculum pressure in the field and the efficacy of measures reducing risks of the onset of head blight epidemics. TaqMan-PCR can also be a powerful tool for similar studies in other crops, e.g., in maize where Fusarium spp. can colonize stalks late in the season and can survive in this niche until the following season $(15,23)$.

\section{ACKNOWLEDGMENTS}

This study was supported by the Dutch Ministry of Agriculture, Nature and Food quality. We thank J. P. Blok (experimental farm Ebelsheerd, Nieuw Beerta), H. T. A. M. Schepers, and P. W. Bakker (PPO Research Unit for Arable Farming, Field Production of Vegetables and Multifunctional Agriculture, Lelystad) for providing field plots.

\section{LITERATURE CITED}

1. Bateman, G. L., Murray, G., Gutteridge, R. J., and Coşkun, H. 1998. Effects of method of straw disposal and depth of cultivation on populations of Fusarium spp. in soil and on brown foot rot in continuous winter wheat. Ann. Appl. Biol. 132:35-47.

2. Bluhm, B. H., Cousin, M. A., and Woloshuk, C. P. 2004. Multiplex realtime PCR detection of fumonisin-producing and trichothecene-producing groups of Fusarium species. J. Food Prot. 67:536-543.

3. Bowen, R. M. 1990. Decomposition of wheat straw by mixed cultures of fungi isolated from arable soil. Soil Biol. Biochem. 22:401-406.

4. Bujold, I., Paulitz, T. C., and Carisse, O. 2001. Effect of Microsphaeropsis sp. on the production of perithecia and ascospores of Gibberella zeae. Plant Dis. 85:977-984.

5. Chelkowski, J. 1998. Distribution of Fusarium species and their mycotoxins in cereal grains. Pages 45-64 in: Mycotoxins in Agriculture and Food Safety. K. K. Sinha and D. Bhatnagar, eds., Marcel Dekker, New York.

6. Dill-Macky, R., and Jones, R. K. 2000. The effect of previous crop residues and tillage on Fusarium head blight of wheat. Plant Dis. 84:7176. 
7. Doohan, F. M., Brennan, J., and Cooke, B. M. 2003. Influence of climatic factors on Fusarium species pathogenic to cereals. Eur. J. Plant Pathol. 109:755-768.

8. European Commission. 2005. Commission regulation (EC) No. 856/2005 of 6 June 2005 amending Regulation (EC) No. 466/2001 as regards Fusarium toxins. Official J. Eur. Union L143:3-8.

9. Fernando, W. G. D., Miller, J. D., Seaman, W. L., Seifert, K., and Paulitz, T. C. 2000. Daily and seasonal dynamics of airborne spores of Fusarium graminearum and other Fusarium species sampled over wheat plots. Can. J. Bot. 78:497-505.

10. Fernando, W. G. D., Paulitz T. C., Seaman, W. L., Dutilleul, P., and Miller, J. D. 1997. Head blight gradients caused by Gibberella zeae from area sources of inoculum in wheat field plots. Phytopathology 87:414421.

11. Greenhouse, S. W., and Geisser, S. 1959. On methods in the analysis of profile data. Psychometrika 24:95-112.

12. Inch, S. A., and Gilbert, J. 2003. Survival of Gibberella zeae in Fusariumdamaged wheat kernels. Plant Dis. 87:282-287.

13. Kessel, G. J. T., de Haas, B. H., Lombaers-van der Plas, C. H., Meijer, E. M. J., Dewey, F. M., Goudriaan, J., van der Werf, W., and Köhl, J. 1999. Quantification of mycelium of Botrytis spp. and the antagonist Ulocladium atrum in necrotic leaf tissue of cyclamen and lily by fluorescence microscopy and image analysis. Phytopathology 89:868876.

14. Kessel, G. J. T., de Haas, B. H., van der Werf, W., and Köhl, J. 2002. Competitive substrate colonization by Botrytis cinerea and Ulocladium atrum in relation to biological control of $B$. cinerea in cyclamen. Mycol. Res. 106:716-728.

15. Khonga, E. B., and Sutton, J. C. 1988. Inoculum production and survival of Gibberella zeae in maize and wheat residues. Can. J. Plant Pathol. 10:232-239.

16. Luongo, L., Galli, M., Corazza, L., Meekes, E., de Haas, L., Lombaersvan der Plas, C., and Köhl, J. 2005. Potential of fungal antagonists for biocontrol of Fusarium spp. in wheat and maize through competition in crop debris. Biocontrol Sci. Technol. 15:229-242.

17. McGee, D. C., Olanya, O. M., Hoyos, G. M., and Tiffany, L. H. 1996.
Populations of Aspergillus flavus in the Iowa cornfield ecosystem in years not favorable for aflatoxin contamination of corn grain. Plant Dis. 80:742746.

18. Ott, R. L., and Longnecker, M. 2001. An Introduction to Statistical Methods and Data Analysis. Duxbury, Pacific Grove, CA.

19. Parry, D. W., Jenkinson P., and McLeod, L. 1995. Fusarium ear blight in small grain cereals - A review. Plant Pathol. 44: 207-238.

20. Pereyra, S. A., and Dill-Macky, R. 2005. Colonization and inoculum production of Gibberella zeae in components of wheat residue. Cereal Res. Commun. 33:755-762.

21. Placinta, C. M., D’Mello, J. P. F., and Macdonald, A. M. C. 1999. A review of worldwide contamination of cereal grains and animal feed with Fusarium mycotoxins. Anim. Feed Sci. Technol. 78:21-37.

22. Shaner, G. 2003. Epidemiology of Fusarium head blight of small grain cereals in North America. Pages 84-119 in: Fusarium Head Blight of Wheat and Barley. K. J. Leonard and W. J. Bushnell, eds. American Phytopathological Society, St. Paul, MN.

23. Sutton, J. C. 1982. Epidemiology of wheat head blight and maize ear rot caused by Fusarium graminearum. Can. J. Plant Pathol. 4:195-209.

24. Waalwijk, C., Kastelein, P., de Vries I., Kerényi, Z., van der Lee, T., Hesselink, T., Köhl, J., and Kema, G. H. J. 2003. Major changes in Fusarium spp. in wheat in The Netherlands. Eur. J. Plant Pathol. 109:743754.

25. Waalwijk, C., van der Heide, R., de Vries, I., van der Lee, T., Schoen, C., Costrel-de-Corainville, G., Haeuser-Hahn, I., Kastelein, P., Köhl, J., Lonnet, P., Demarquet, T., and Kema, G. H. J. 2004. Quantitative detection of Fusarium species in wheat using TaqMan. Eur. J. Plant Pathol. 110:481-494.

26. Windels, C. E., and Kommedahl, T. 1984. Late-season colonization and survival of Fusarium graminearum group II in cornstalks in Minnesota. Plant Dis. 68:791-793.

27. Yli-Mattila, T., Paavanen-Huhtala, S., Parikka, P., Hietaniemi, V., Jestoi, M., and Rizzo, A. 2004. Real-time PCR detection and quantification of Fusarium poae as compared to mycotoxin production in grains in Finland. Pages 422-425 in: Proc. 2nd International Symposium on Fusarium Head Blight, Michigan State University, East Lansing. 